\title{
Penerapan Model Pembelajaran Berbasis Masalah Berbantuan Pictorial Riddle untuk Meningkatkan Hasil Belajar Kognitif dan Keterampilan Berpikir Kritis Peserta Didik pada Materi Pokok Elastisitas dan Hukum Hooke Kelas XI IPA 2 SMA Negeri 1 Loghia
}

\author{
Wa Ode Hasriani ${ }^{1)^{*}}$, Muhammad Anas ${ }^{2)}$, La Sahara ${ }^{2)}$ \\ 1)* Alumni Jurusan Pendidikan Fisika FKIP Universitas Halu Oleo \\ ${ }^{2)}$ Dosen Jurusan Pendidikan Fisika FKIP Universitas Halu Oleo \\ Email: waodehasriani97@gmail.com
}

\begin{abstract}
This study aims to: 1) describe the improvement of student learning outcomes in learning physics class XI IPA2 SMA Negeri 1 Loghia which is taught by using a problem-based learning model assisted by pictorial riddle on the subject matter of elasticity and hooke law. 2) describe the improvement of students' critical thinking skills in physics learning class XI IPA2 SMA Negeri 1 Loghia on the subject matter of elasticity and hooke law taught by using problem-based learning models assisted by pictorial riddle 3) describe the completeness of students learning in physics learning class XI IPA2 Loghia State High School 1, which is taught by using a pictorial riddle-based problem-based learning model on the subject of elasticity and hooke law. The data analysis was performed by descriptive statistics. From the analysis of the data obtained the average of cognitive learning outcomes of students in the first cycle is 74.71. The average critical thinking skills in the first cycle are indicators giving 38.79 simple explanations, building basic skills 28.45, concluding 38.79, making further explanation 31.90 and indicators of strategy and tactics 50.86. As for the percentage of mastery learning classically in the first cycle of 65.52\%. In the second cycle obtained the average of cognitive learning outcomes of 79.83. The average critical thinking skills in the second cycle of the indicators provide a simple explanation of 57.76, building basic skills 84.48, concluding 93.10, making further explanation 74.13 and indicators of strategy and tactics 88.79. While the percentage of mastery learning classical students in the first cycle amounted to $79.31 \%$. Based on the results of the research and discussion it can be concluded that the application of problem based learning model assisted by pictorial riddle can improve cognitive learning outcomes and critical thinking skills.
\end{abstract}

Keywords: Learning Outcomes, Critical Thinking, Problem Based Learning, Pictorial Riddle

\begin{abstract}
Abstrak: Penelitian ini bertujuan untuk: 1) mendeskripsikan peningkatan hasil belajar kognitif peserta didik pada pembelajaran Fisika kelas XI IPA 2 SMA Negeri 1 Loghia yang diajarkan dengan menggunakan model pembelajaran berbasis masalah berbantuan pictorial riddle pada materi pokok elastisitas dan hukum hooke. 2) mendeskripsikan peningkatan keterampilan berpikir kritis peserta didik pada pembelajaran Fisika kelas XI IPA 2 SMA Negeri 1 Loghia pada materi pokok elastisitas dan hukum hooke yang diajarkan dengan menggunakan model pembelajaran berbasis masalah berbantuan pictorial riddle 3) mendeskripsikan ketuntasan belajar peserta didik pada pembelajaran Fisika kelas XI IPA 2 SMA Negeri 1 Loghia yang diajarkan dengan menggunakan model pembelajaran berbasis masalah berbantuan pictorial riddle pada materi pokok elastisitas dan hukum hooke. Data yang dikumpulkan pada penelitian ini adalah hasil belajar kognitif dan keterampilan berpikir kritis yang diperoleh dari tes siklus I dan siklus II. Analisis data yang dilakukan statistik deskriptif. Dari analisis data diperoleh nilai rata-rata hasil belajar kognitif peserta didik pada siklus I yaitu 74,71. Rata-rata keterampilan berpikir kritis pada siklus I yaitu indikator memberikan penjelasan sederhana 38,79, membangun keterampilan dasar 28,45, menyimpulkan 38,79, membuat penjelasan lebih lanjut 31,90 dan indikator strategi dan taktik 50,86. Sedangkan untuk persentase ketuntasan belajar secara klasikal pada siklus I sebesar 65,52\%. Pada siklus II diperoleh nilai rata-rata hasil belajar kognitif sebesar 79,83. Rata-rata keterampilan berpikir kritis pada siklus II yaitu indikator memberikan penjelasan sederhana 57,76, membangun keterampilan dasar 84,48, menyimpulkan 93,10, membuat penjelasan lebih lanjut 74,13 dan indikator strategi dan taktik 88,79 . Sedangkan persentase ketuntasan belajar secara klasikal peserta didik pada siklus I sebesar $79,31 \%$.
\end{abstract}

Kata Kunci: Hasil Belajar, Berpikir Kritis, Pembelajaran Berbasis Masalah, Pictorial Riddle 


\section{PENDAHULUAN}

Pendidikan nasional yang berkualitas dapat tercapai apabila keseluruhan komponen pendidikan saling berkaitan secara terpadu. Komponen pendidikan yang dimaksud meliputi tujuan pendidikan, peserta didik, guru sebagai tenaga pendidik, model pembelajaran, lingkungan pendidikan dan fasilitas pendidikan. Dalam memadukan komponen-komponen tersebut, tenaga pendidik memiliki peran yang sangat penting. Dimana, guru harus mampu memahami materi pembelajaran yang akan diajarkan kepada peserta didik serta mampu memilih model pembelajaran yang sesuai dengan materi tersebut. Data hasil ulangan harian peserta didik di SMA Negeri 1 Loghia pada kelas XI IPA 2 dan XI IPA $\mathrm{IPhun}_{3}$ ajaran 2018/2019 pada materi pokok Elastisitas dan Hukum Hooke menunjukan bahwa masih banyak peserta didik yang nilainya belum memenuhi Kriteria Ketuntasan Minimal (KKM), dimana KKM yang ditetapkan di sekolah tersebut untuk mata pelajaran fisika adalah 75 . Untuk kelas XI IPA 2 dari 25 peserta didik, hanya 8 orang saja yang memenuhi KKM (32\% tuntas). Selebihnya tidak memenuhi $\mathrm{KKM}$ (68\% tidak tuntas). Sedangkan pada kelas XI $\mathrm{IPA}_{3}$ hanya 13 orang yang memenuhi KKM dari 25 peserta didik juga (52\% tuntas dan $48 \%$ tidak tuntas). Hal ini menunjukan bahwa peserta didik butuh perhatian khusus agar dapat meningkatkan persentase ketuntasan hasil belajar kognitifnya.

Hasil observasi yang dilakukan di SMA Negeri 1 Loghia, diperoleh beberapa informasi mengenai kegiatan pembelajaran. Berdasarkan hasil wawancara dengan peserta didik bahwa mereka masih mengalami kesulitan dalam memahami pelajaran fisika. Hal ini terjadi karena pada proses pembelajaran tidak diberikan contoh nyata yang sering ditemui peserta didik dalam kehidupan sehari-hari dan tidak dilaksanakan diskusi kelompok yang melibatkan seluruh peserta didik. Selain itu juga, kesulitan mereka dalam memahami pelajaran karena peserta didik kurang aktif dalam proses pembelajaran atau proses pembelajaran yang berlangsung berorientasi pada guru. Dalam hal ini, peserta didik hanya mendengarkan penjelasan guru dan jarang ada interaksi antara guru dan peserta didik dalam proses pembelajaran. Ketika guru memberikan pertanyaan, peserta didik hanya mampu menjawab pertanyaan seputar pengertian saja karena peserta didik hanya menghafalkan teori-teori yang ada, tetapi tidak memahaminya dengan baik. Ketika guru memberikan pertanyaan tentang penerapan konsep, peserta didik tidak mampu menjawab pertanyaan tersebut. Kemudian, apabila dihadapkan pada suatu permasalahan fisika, peserta didik lebih sering mengaplikasikan ke dalam rumus tanpa melakukan analisa lebih lanjut untuk mencocokkan persamaan yang dapat digunakan. Dan pada saat peserta didik diberi kesempatan untuk bertanya, pertanyaan yang dibuat oleh peserta didik belum menunjukan bahwa mereka telah mampu berpikir kritis. Hal ini menunjukan bahwa keterampilan berpikir kritis peserta didik masih tergolong rendah.

Berdasarkan permasalahan diatas, salah satu tindakan yang bisa dilakukan untuk memperbaiki proses pembelajaran fisika adalah dengan menerapkan model pembelajaran berbasis masalah. Problem Based Learning atau dalam bahasa Indonesia disebut sebagai Pembelajaran Berbasis Masalah adalah penyajian situasi autentik dan bermakna yang bertindak sebagai landasan bagi penyelidikan dan inkuiri peserta didik. Oleh karena itu, peserta didik lebih termotivasi dalam proses pembelajaran sehingga dapat mengembangkan keterampilan berpikir, memecahkan masalah dan peserta didik menjadi pembelajar yang mandiri. Hal ini berdasarkan penelitian yang dilakukan oleh Ikhwanul Muslimin dkk dan U. Setyorini, dkk (2011). Faktor lain yang dapat mempengaruhi hasil belajar dan keterampilan berpikir kritis peserta didik adalah penggunaan media pembelajaran. Di SMA Negeri 1 Loghia, masih jarang menggunakan media pembelajaran. Untuk menguasai konsep dalam mata pelajaran fisika, selain menggunakan model pembelajaran yang tepat juga harus menggunakan media pembelajaran yang tepat pula. Salah satu contoh media pembelajaran yang dapat digunakan adalah media yang menampilkan gambar-gambar agar peserta didik lebih tertarik untuk belajar. Media yang dapat digunakan dalam hal ini adalah pictorial riddle. Pictorial Riddle disini merupakan media yang menampilkan gambar yang mengandung permasalahan yang kemudian peserta didik dituntut untuk menyelesaikan sendiri permasalahan itu. Sehingga dalam proses penyelesaian masalah tersebut terbentuk pengetahuan baru yang dapat meningkatkan hasil belajar dan keterampilan berpikir kritis peserta didik. Berdasarkan penelitian yang dilakukan oleh Lesy Luzyawati (2017) bahwa dengan menerapkan model pembelajaran Inquiry Pictorial Riddle, rata-rata keterampilan berpikir kritis seluruh siswa di kelas XI MIPA 6 SMA Negeri 1 Sindang Indramayu yaitu 77\% dengan kategori baik.

Berdasarkan latar belakang masalah yang telah diuraikan, maka peneliti mengkaji tentang "Penerapan Model Pembelajaran Berbasis Masalah Berbantuan Pictorial Riddle untuk Meningkatkan Hasil Belajar dan Keterampilan Berpikir Kritis Peserta Didik pada Materi Pokok Elastisitas dan Hukum Hooke Kelas XI IPA 2 SMA Negeri 1 Loghia." 


\section{METODE}

Penelitian ini merupakan Penelitian Tindakan Kelas (PTK), yang dilakukan dengan menerapkan model pembelajaran berbasis masalah berbantuan pictorial riddle sebagai alternatif tindakan untuk meningkatkan hasil belajar kognitif dan keterampilan berpikir kritis peserta didik pada materi pokok elastisitas dan hukum hooke kelas XI IPA 2 SMA Negeri 1 Loghia.

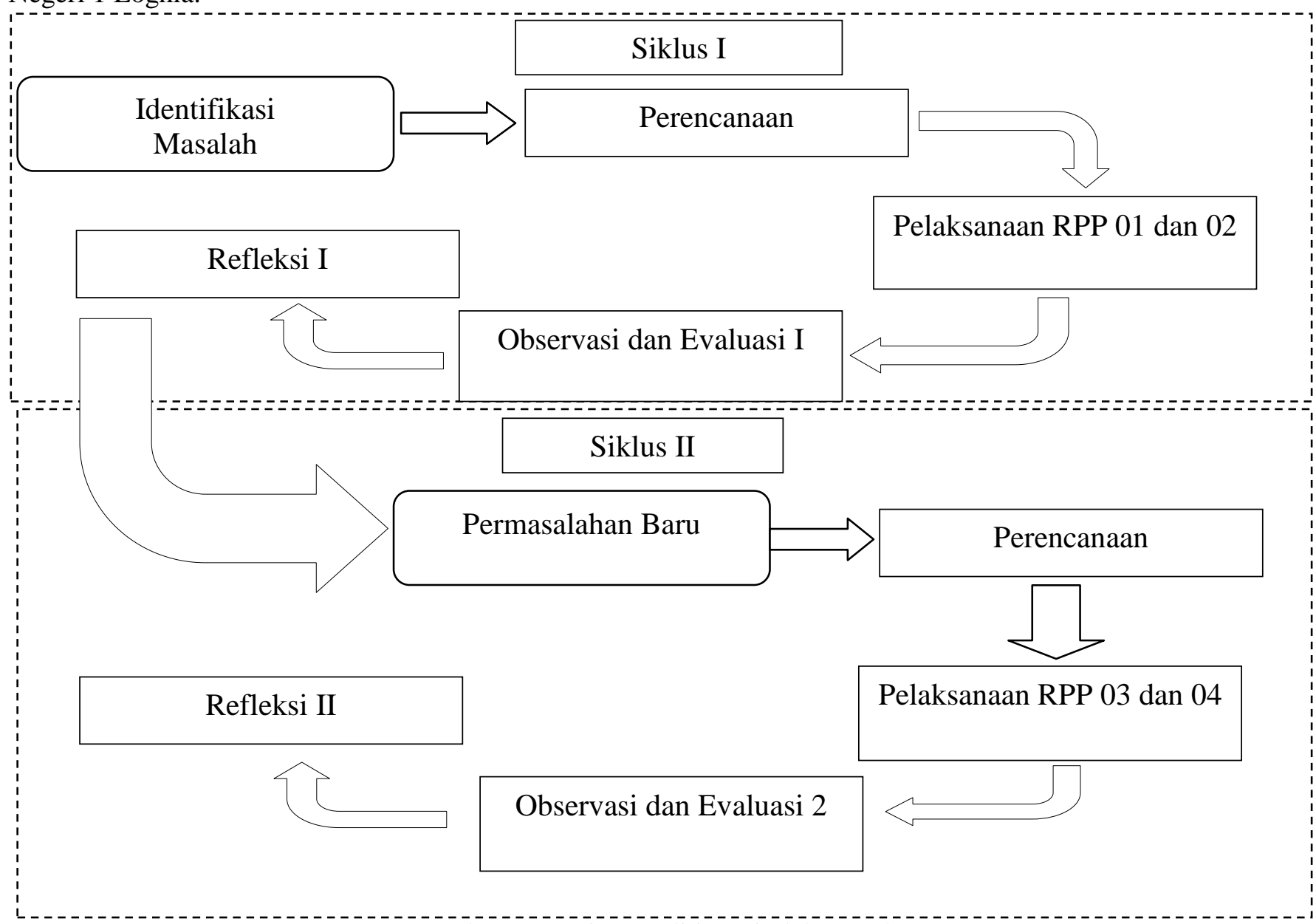

Gambar 1 Desain Penelitian Tindakan Kelas

Teknik analisis data yang digunakan berupa analisis deskriptif. Terdapat dua jenis instrumen yang digunakan dalam penelitian tindakan kelas ini, yaitu tes dan non tes. Tes: Data mengenai hasil belajar kognitif dan keterampilan berpikir kritis peserta didik diambil menggunakan tes hasil belajar (tes siklus) dengan bentuk tes berupa tes esai. Non Tes: Alat pengumpulan data dalam bentuk non tes dapat dilakukan dalam bentuk observasi. Observasi dilakukan untuk mengamati dan mengevaluasi pelaksanaan
Penelitian ini dilakukan pada semester ganjil Tahun Ajaran 2019/2020 di SMA Negeri 1 Loghia. Subjek penelitian ini adalah peserta didik Kelas XI $\mathrm{IPA}_{2}$ yang terdaftar pada semester ganjil Tahun Ajaran 2019/2020 dengan jumlah peserta didik 29 orang. Desain penelitian yang digunakan adalah desain penelitian tindakan kelas seperti gambar 1 berikut.

Siklus I 
Tabel 1 Data Keterlaksanaan Model Pembelajaran Berbasis Masalah

\begin{tabular}{ccc}
\hline & Siklus I & \multicolumn{2}{c}{ Siklus II } \\
\hline Jumlah & 27 & 37 \\
\hline Rata-rata & 2,5 & 3,4 \\
\hline Kategori & Baik & \multicolumn{2}{c}{ Sangat baik } \\
\hline Tabel 2 Pengkategorian Nilai Hasil Belajar Kognitif Peserta Didik \\
\hline Nilai Rata-rata & 74,71 & 79,83 \\
\hline Nilai Maksimum & 100 & 100 \\
\hline Nilai Minimum & 13,33 & 40 \\
\hline Standar Deviasi & 21,52 & 15,3 \\
\hline Jumlah T & 19 & 23 \\
\hline Jumlah BT & 10 & $69,31 \%$ \\
\hline Presentase T & $65,52 \%$ & $20,69 \%$
\end{tabular}

Berdasarkan analisis deskriptif pada Tabel 1 dan Tabel 2 dapat dilihat bahwa rata-rata hasil belajar kognitif peserta didik pada siklus I hanya mencapai 74,71 dengan variasi nilai antara 13,33 sampai 100 . Nilai rata-rata peserta didik ini belum mencapai kriteria ketuntasan minimum yang telah ditetapkan yaitu sebesar 75. Adapun persentase peserta didik yang telah mencapai nilai $\geq 75$ sebesar $65,52 \%$ berjumlah 19 orang sedangkan yang belum tuntas sebesar $34,48 \%$ berjumlah 10 orang. Dari hasil belajar kognitif ini, hasil yang diperoleh sudah cukup baik namun belum memenuhi syarat keberhasilan tindakan yang telah ditetapkan yaitu minimal $75 \%$ peserta didik yang telah mencapai nilai $\geq 75$.

Dari lima butir soal tes hasil belajar kognitif, peserta didik masih banyak keliru pada saat melakukan perhitungan. Adapun kesalahan yang lain, peserta didik masih kebingungan untuk menggunakan persamaan yang mana dalam menyelesaikan soal. Olehnya itu, guru harus menekankan penguasaan konsep pada materi selanjutnya dengan lebih memaksimalkan penggunaan media pembelajaran pictorial riddle dan harus lebih banyak memberikan latihan dalam mengerjakan soal dalam bentuk perhitungan. Selain itu, guru juga harus mampu memupuk rasa ingin tahu peserta didik sehingga mereka lebih banyak bertanya agar lebih mengerti materi yang dipelajarinya.

Setelah melakukan perbaikan terhadap penerapan model pembelajaran berbasis masalah yang masih kurang pada siklus I, hasil belajar kognitif peserta didik mengalami peningkatan pada siklus II. Pada siklus II ini guru melakukan perbaikan berdasarkan refleksi yang telah dilakukan sebelumnya. Sehingga hal tersebut berdampak pada meningkatnya hasil belajar kognitif peserta didik seperti yang terlihat pada tabel 4.3, dimana diperoleh nilai rata-rata hasil belajar peserta didik pada siklus II sebesar 79,83, hasil yang diperoleh ini lebih tinggi dibandingkan pada siklus I. Pada siklus ini terdapat 23 orang peserta didik atau $79,71 \%$ yang memperoleh nilai $\geq 75$ (tuntas) dan 6 orang atau $20,69 \%$ tidak tuntas. $<75$.

Berdasarkan kriteria keberhasilan tindakan, yaitu jika presentasi ketuntasan belajar peserta didik secara klasikal $\geq 75 \%$ maka hasil belajar yang diperoleh peserta didik sudah memenuhi kriteria keberhasilan tindakan. Sehingga dapat dikatakan penelitian yang dilakukan telah berhasil. Namun, pada tes hasil belajar kognitif ini dapat dilihat bahwa ada beberapa orang peserta didik yang nilainya pada siklus I tuntas namun pada siklus II menjadi tidak tuntas. Atau nilai hasil belajarnya menurun walaupun tetap memenuhi kriteria ketuntasan minimal. Hal tersebut terjadi karena, dari segi materi, pada siklus II lebih sulit dari pada materi pada siklus I. Peserta didik SMA Negeri 1 Loghia khususnya kelas XI IPA ${ }_{2}$ beberapa orang masih lemah dalam hal perhitungan, dimana dalam melakukan perhitungan mereka masih sering keliru. Sedangkan materi pada siklus II membutuhkan keterampilan dalam 
operasi matematika yang lebih tinggi dibandingkan dengan siklus I. Dan dari segi soal yang diberikan dapat dilihat bahwa dari nomor satu sampai nomor lima semuanya membutuhkan keterampilan hitung. Sehingga, menjadi hal yang wajar jika nilai peserta didik pada sikus II mengalami penurunan.

Dengan melihat hasil belajar tersebut menunjukan bahwa dengan menerapkan model pembelajaran berbasis masalah dapat meningkatkan hasil belajar kognitif peserta didik. Peningkatan tersebut telah sesuai dengan teori yang dijelaskan oleh Mulyasa (2006) dalam Cut Eka yang menyatakan bahwa dari segi hasil, dikatakan berhasil jika setidakna terdapat $75 \%$ siswa yang mengalami perubahan positif dan output yang bermutu tinggi.

\section{Keterampilan Berpikir Kritis}

Hasil analisis deskriptif terhadap keterampilan berpikir kritis peserta didik dapat dilihat padaTabel 3 .

Tabel 3 Rata-rata Indikator Keterampilan Berpikir kritis Peserta didik

\begin{tabular}{lccl}
\hline NO & Indikator Keterampilan Berpikir Kritis & Siklus I & Kategori \\
\hline 1. & Memberikan Penjelasan Sederhana & 37,93 & Sangat Rendah \\
\hline 2. & Membangun keterampilan dasar & 28,45 & Sangat Rendah \\
\hline 3. & Menyimpulkan & 38,79 & Sangat Rendah \\
\hline 4. & Membuat penjelasan lebih lanjut & 31,03 & Sangat Rendah \\
\hline 5. & Strategi dan taktik & 50,86 & Rendah \\
\hline
\end{tabular}

Berdasarkan hasil analisis deskriptif keterampilan berpikir kritis peserta didik pada Tabel 4.3 dan 4.7 menunjukan bahwa peserta didik mengalami kesulitan dalam hal menyelesaikan soal-soal yang menggunakan indikator keterampilan berpikir kritis. Dalam hal ini memberikan penjelasan sederhana, membangun keterampilan dasar, menyimpulkan, membuat penjelasan lebih lanjut dan strategi dan taktik. Hal ini terbukti dari persentase keterampilan berpikir kritis peserta didik pada indikator memberikan penjelasan sederhana, membangun keterampilan dasar, menyimpulkan dan membuat penjelasan lebih lanjut persentase berpikir kritis yang diperoleh berada diantara $0<X \leq 43,75$ yang termasuk dalam kategori sangat rendah.

Indikator strategi dan taktik diperoleh persentase keterampilan berpikir kritis sebesar 50,86 yang masuk dalam kategori rendah. Hal tersebut menunjukan bahwa keterampilan berpikir kritis peserta didik harus diasah dengan baik. Rendahnya keterampilan berpikir kritis peserta didik sudah terlihat pada saat proses pembelajaran berlangsung. Dimana pada saat dilaksanakan proses orientasi masalah, peserta didik tidak dapat memberikan pertanyaan berdasarkan gambar yang ditampilkan. Selain itu, beberapa pertanyaan dalam LKPD tidak dapat diselesaikan dengan baik oleh peserta didik. Saat proses belajar berlangsung, peserta didik kesulitan dalam hal membuat pertanyaan, membuat hipotesis, menarik kesimpulan dan berinteraksi dengan orang lain (diskusi). Permasalahan ini terjadi bukan hanya karena faktor peserta didik saja, namun guru ikut mengambil peran disini. Sehingga guru harus lebih maksimal lagi dalam membimbing peserta didik.

Permasalahan lain yang mempengaruhi sehingga banyak peserta didik yang masih salah atau bahkan banyak soal keterampilan berpikir kritis yang tidak terjawab karena peserta didik fokus mengerjakan soal tes hasil belajar kognitif dan juga kemungkinan mereka tidak terbiasa mengerjakan soal yang terlalu banyak, karena biasanya pada saat ulangan guru hanya memberikan empat sampai enam butir soal saja. Sehingga pada saat peserta didik menemukan soal yang 
terlalu banyak, mereka tidak dapat membagi waktu dengan baik pada saat pengerjaannya. Sehingga, soal keterampilan berpikir kritis diwaktu-waktu terakhir baru dikerjakan. Bahkan ada salah satu peserta didik yang tidak mengerjakan sama sekali soal keterampilan berpikir kritisnya.

Gambaran keterlaksanaan pembelajaran dengan model pembelajaran berbasis masalah dalam meningkatkan keterampilan berpikir kritis peserta didik pada siklus II menunjukan bahwa langkah-langkah model pembelajaran berbasis masalah yang memiliki peran untuk melatih keterampilan berpikir kritis peserta didik telah berfungsi dengan baik, sehingga keterampilan berpikir kritis peserta didik kelas XI IPA SMA Negeri 1 Loghia mengalami peningkatan dari siklus I. Berdasarkan analisis deskriptif masing-masing indikator keterampilan berpikir kritis pada siklus II terlihat bahwa rata-rata keterampilan berpikir kritis untuk indikator memberikan penjelasan sederhana meningkat menjadi 57,76 dengan kategori rendah. Walaupun tidak sampai pada kategori sedang, namun mengalami peningkatan dari kategori sangat rendah menjadi rendah.

Indikator membangun keterampilan dasar, menyimpulkan dan strategi dan taktik rata-rata yang diperoleh adalah 84,48, 93,10 dan 88, 79 dan berada pada kategori sangat tinggi. Sedangkan untuk indikator membuat penjelasan lebih lanjut rata-ratanya 74,13 dengan kategori tinggi. Peningkatan keterampilan berpikir kritis juga didukung dengan peningkatan aktivitas belajar peserta didik ketika mengisi LKPD. Dimana nilai dari LKPD yag mereka peroleh pada siklus II juga meningkat dari siklus I. Hal tersebut menjukan bahwa penerapan model pembelajaran berbasis masalah berbantuan pictorial riddle telah meningkatkan keterampilan berpikir kritis peserta didik.

\section{KESIMPULAN}

1. Hasil belajar kognitif peserta didik kelas XI IPA SMA Negeri 1 Loghia materi pokok Elastisitas dan Hukum Hooke yang diajar dengan menggunakan model pembelajaran berbasis masalah berbantuan pictorial riddle mengalami peningkatan dimana pada siklus I diperoleh nilai rata-rata sebesar 74,71 sedangkan pada siklus II diperoleh nilai rata-rata sebesar 79,83 .

2. Keterampilan berpikir kritis peserta didik kelas XI $\mathrm{IPA}_{2}$ SMA Negeri 1 Loghia materi pokok Elastisitas dan Hukum Hooke yang diajar dengan menggunakan model pembelajaran berbasis masalah berbantuan pictorial riddle mengalami peningkatan.
3. Ketuntasan belajar fisika peserta didik kelas XI IPA SMA Negeri 1 Loghia yang diajar menggunakan model pembelajaran berbasis masalah berbantuan pictorial riddle pada materi pokok elastisitas dan hukum hooke secara klasikal sudah tuntas.

\section{DAFTAR PUSTAKA}

Achmad, A. Memahami Berpikir Kritis. Tersedia: http://researchengines.com/1007arief3.html

Eka, P. 2017. Upaya Peningkatan Hasil Belajar Fisika Siswa Melalui Penerapan Model Pembelajaran Problem Based Learning. Universitas Syiah Kuala. Aceh.

Jihad, A. 2013. Evaluasi Pembelajaran, Multi Pressindo, Yogyakarta.

Afandi, M, Chamala, E, Puspita, O W. 2013. Model dan Metode Pembelajaran di Sekolah. UNISSULA Press. Semarang.

Alwasilah, C. 2010. Contextual Teaching and Learning : Menjadikan kegiatan Belajar-Mengajar Mengasyikkan dan Bermakna. Kaifa. Bandung.

Arikunto. 2005. Manajemen Penelitian. Penerbit PT Rineka Cipta. Jakarta.

Baharudin, H. 2010. Teori Belajar dan Pembelajaran. AR- Ruzz Media. Jogjakarta.

Ennis, R.H. 1985. Developing Mind: Goal for aCritical Thingking Curriculum. Arethur L. Costa Editor.

Hamalik, O. 2008. Perencanaan pengajaran berdasarkan pendekatan sistem. Bumiaksara. Bandung.

Herlinda, Swistoro E, Risdinto E. 2017. Pengaru Model Problem Based Learning (PBL) Terhadap Hasil Belajar, Kemampuan Pemecahan Masalah Fisika dan Minat Belajar Siswa pada Materi Fluida Statis Di SMA Negeri 1 Lebong Sakti. Universitas Bengkulu. Bengkulu.

Husnidar, I M dan Syamsul R. 2014. Penerapan Model Pembelajaran Berbasis Masalah untuk Meningkatkan Kemampuan Berpikir Kritis dan Disposisi Matematis Siswa. Jurnal Didaktik Matematika Vol. 1, No. 1. Universitas Syiah Kuala. Banda Aceh.

Luzyawati, L. 2017. Analisis Kemampuan Berpikir Kritis Siswa SMA Materi Alat Indera Melalui Model Pembelajaran Inquiry Pictorial Riddle. Universitas Wiralodra. Indramayu.

Marlinasari. 2013. Pengaruh Penerapan Metode Inquiry dengan Media Pictorial Riddle terhadap Hasil Belajar Siswa dalam Pembelajaran IPA. Universitas Tanjungpura. Pontianak. 
Sanjaya, W. 2008. Strategi Pembelajaran Berorientasi Standar Proses Pendidikan. Kencana Prenada Media Group. Jakarta.

Sardiman. 2011. Interaksi dan Motivasi Belajar dan Mengajar. Rajaali Press. Jakarta.

Setyorini U, Sukiswo, Subali B. 2011. Penerapan Model Problem Based Learning untuk Meningkatkan Kemampuan Berpikir Kritis Siswa SMP. Universitas Negeri Semarang Semarang. Semarang.

Slameto. 2003. Belajar dan Faktor-Faktor yang Mempengaruhinya. IKIP UKSW. Salatiga.

Sudjana. 2006. Metoda Statistika. Tarsito. Bandung.
Supardi. 2015. Penilaian Autentik Pembelajaran Afektif, Kognitif, dan Psikomotor (Konsep dan Aplikasi). PT Raja Grafindo Persada. Jakarta.

Supriyanti E, Ika O, Yuli D, Sirfa L, Salsabila, Adi B. 2018. Profil Keterampilan Berpikir Kritis Siswa SMA di Sragen pada Materi Sistem Reproduksi. Universitas Sebelas Maret. Surakarta.

Syarif Mohamad, S. 2016. Strategi Pembelajaran. PT Raja Grafindo Persada. Jakarta.

Trianto. 2007. Model-model Pembelajaran Inovatif. Grasindo. Jakarta.

Usman. 2001. Upaya Optimalisasi Kegiatan Belajar Mengajar. Remaja Rosdakarya. Bandung. 